\title{
Inhibitory effect of $\alpha$-solanine on esophageal carcinoma in vitro
}

\author{
LEI WANG ${ }^{1}$, QIAN-QIAN SUN ${ }^{3}$, SHI-JIE ZHANG ${ }^{2}$, YU-WEN DU ${ }^{3}$, YUAN-YUAN WANG ${ }^{3}$, \\ WEN-QIAO ZANG ${ }^{3}$, XIAO-NAN CHEN $^{3}$ and GUO-QIANG ZHAO ${ }^{3}$
}

\begin{abstract}
Departments of ${ }^{1}$ Emergency and ${ }^{2}$ Clinical Laboratory, The First Affiliated Hospital of Zhengzhou University, Zhengzhou, Henan 450052; ${ }^{3}$ College of Basic Medical Sciences, Zhengzhou University, Zhengzhou, Henan 450001, P.R. China
\end{abstract}

Received June 11, 2015; Accepted June 7, 2016

DOI: $10.3892 / \mathrm{etm} .2016 .3500$

\begin{abstract}
. $\alpha$-solanine, a bioactive component and one of the major steroidal glycoalkaloids in potatoes, has been observed to inhibit growth and induce apoptosis in cancer cells. However, the antitumor efficacy of $\alpha$-solanine on esophageal carcinoma has yet to be fully elucidated. In the present study, the antitumor efficacy of $\alpha$-solanine against human esophageal carcinoma cells was investigated. It was determined that $\alpha$-solanine inhibited the growth and proliferation of human esophageal EC9706 and Eca109 cancer cells in a dose-dependent manner, as well as the cell migration and invasion. In addition, the apoptotic rate was increased in the cancer cells treated with $\alpha$-solanine in a dose-dependent manner, compared with that of the control group $(\mathrm{P}<0.05)$. The expression levels of tumor metastasis-related proteins, including matrix metalloproteinase (MMP)-2 and MMP-9, were reduced in the cells treated with $\alpha$-solanine, as compared with the control group. Conversely, significantly higher expression levels of E-cadherin were detected in the $\alpha$-solanine-treated groups, as compared with the control group $(\mathrm{P}<0.05)$. Therefore, the current results provide a novel insight into the anti-tumor mechanism of $\alpha$-solanine, and suggest that $\alpha$-solanine is a potential agent for the prevention and treatment of esophageal carcinoma.
\end{abstract}

\section{Introduction}

Esophageal carcinoma (EC) is a global health problem ranked eighth in terms of incidence, and sixth in terms of mortality $(1,2)$. The majority of primary tumors in patients

Correspondence to: Dr Shi-Jie Zhang, Department of Clinical Laboratory, The First Affiliated Hospital of Zhengzhou University, 1 Jianshe Road, Zhengzhou, Henan 450052, P.R. China

E-mail: zsj03@zzu.edu.cn

Dr Guo-Qiang Zhao, College of Basic Medical Sciences, Zhengzhou University, 100 Kexue Avenue, Zhengzhou, Henan 450001, P.R. China

E-mail: zhaogq@zzu.edu.cn

Key words: $\alpha$-solanine, esophageal carcinoma, apoptosis, tumor metastasis, proliferation are curable by surgical resection, however, due to a lack of distinct early symptoms, patients are often diagnosed at advanced stages, and more than half of patients present with metastases (3). The remaining patients without advanced stage disease receive surgery, chemotherapy and radiotherapy for treatment, however, the majority eventually succumb to metastases. Therefore, in order to advance the current radiotherapy and chemotherapy, there is an increasing interest in developing an effective agent to inhibit tumor cell prolification and restrain the metastasic capability of EC cells.

In recent years, interest in the use of traditional medicines for the prevention and treatment of tumors has increased, and various therapies have been employed as monotherapy or in combination with conventional medicine $(4,5)$. Glycoalkaloids (GAs) are natural toxic compounds present in a number of vegetables and plants (6). Previous findings showed that glycoalkaloids exert a strong inhibitory effect on tumor growth in animals as a result of their cytotoxic effects on tumor cells $(7,8) . \alpha$-solanine, a bioactive component and one of the major steroidal glycoalkaloids in potatoes, is predominantly detected in the tuber crop potato and the nightshade plant. It was previously demonstrated that $\alpha$-solanine causes growth inhibition and apoptosis induction in multiple cancer cells $(9,10)$. In addition, certain studies have indicated that $\alpha$-solanine possesses anti-metastasis activity in various cancers (11-17).

Thus, to determine the potential contribution of $\alpha$-solanine to EC therapy, and the underlying molecular mechanisms regarding the association between $\alpha$-solanine and esophageal tumorigenesis, the aim of the present study was to examine the effect of $\alpha$-solanine on the EC9706 and Eca109 cell lines.

\section{Materials and methods}

Cell lines and reagents. $\alpha$-solanine was purchased from Sigma-Aldrich (St. Louis, MO, USA), and dissolved in dimethylsulfoxide for storage at $-20^{\circ} \mathrm{C}$. Human esophageal squamous carcinoma cell lines, EC9706 and Eca109, were purchased from Shanghai Institutes for Biological Sciences, Chinese Academy of Sciences (Shanghai, China). The cells were routinely cultured in DMEM supplemented with $10 \%$ heat-inactivated fetal bovine serum (FBS; both Gibco; Thermo Fisher Scientific, Inc., Waltham, MA, USA), 100 U/ml penicillin and $100 \mu \mathrm{g} / \mathrm{ml}$ streptomycin in a humidified cell incubator with an atmosphere of $5 \% \mathrm{CO}_{2}$ at $37^{\circ} \mathrm{C}$. 
In vitro cell proliferation assay. EC9706 and Eca109 cell lines in the logarithmic phase of growth were seeded into 96-well plates at a density of $1 \times 10^{4}$ cells/well. Subsequent to the starving of cells with serum-free medium containing $0.1 \%$ BSA for $24 \mathrm{~h}$, once cell adhesion was complete, the cells were exposed to a range of concentrations of $\alpha$-solanine $(10,20,40$ and $60 \mu \mathrm{g} / \mathrm{ml}$ ) for 24,48 and $72 \mathrm{~h}$. The cells were then treated with a Cell Counting kit-8 (CCK-8) solution (Dojindo Molecular Technologies, Inc., Kumamoto, Japan) and incubated for a further $2 \mathrm{~h}$. Cell proliferation was determined by measuring the absorbance at $450 \mathrm{~nm}$ using a plate reader (Model 680; cat. no. 168-1000; Bio-Rad Laboratories, Inc., Hercules, CA, USA). Triplicate parallel experiments were performed for each concentration. The rate of inhibition was calculated using the equation: Rate of growth inhibition $(\%)=\left(\mathrm{OD}_{\text {control }}-\mathrm{OD}_{\text {treated }}\right) / \mathrm{OD}_{\text {control }} \times 100 \%$, where $\mathrm{OD}$ was the optical density.

Colony-forming survival assay. The overall survival of the cells treated with $\alpha$-solanine was assessed by the rate of colony formation. EC9706 and Eca109 cells were seeded into 6-well plates for $24 \mathrm{~h}$. Following this, the cells were washed with DMEM, trypsinized and counted. Base Agar Matrix Layer (1.5 ml; GenMed Scientifics, Inc, Shanghai, China) was dispensed into each well of a 12-well plate. The plate was maintained at $18-25^{\circ} \mathrm{C}$ until solid. Subsequently, $1.5 \mathrm{ml}$ growth agar layer consisting cells were added into each well and the plate was kept at room temperature until the growth layer congealed. A further $500 \mu$ l culture media containing various concentrations of $\alpha$-solanine $(0,20,40$ and $60 \mu \mathrm{g} / \mathrm{ml})$ was added to the surface of the growth layer. The cells were then incubated at $37^{\circ} \mathrm{C}$ with $5 \% \mathrm{CO}_{2}$ until colony formation was visible, which usually occurred between 10 and 14 days. The colonies with $>50$ cells were considered to be surviving colonies. The plating efficiency was calculated by dividing the average number of colonies per well by the amount of cells plated. Survival fractions were calculated by normalization to the plating efficiency of appropriate control groups.

Cell migration and invasion assays. Transwell filters were coated with Matrigel $(3.9 \mathrm{~g} / 1,40 \mu \mathrm{l})$ on the upper surface of the polycarbonic membrane $(6.5 \mathrm{~mm}$ in diameter, $8 \mu \mathrm{m}$ pore size). The Matrigel, after solidifying at $37^{\circ} \mathrm{C}$ for $30 \mathrm{~min}$, served as the extracellular matrix for tumor cell invasion analysis. Subsequent to treatment with different concentrations $(20,40$ and $60 \mu \mathrm{g} / \mathrm{ml})$ of $\alpha$-solanine for $24 \mathrm{~h}, 200 \mu \mathrm{l}$ serum-free cell suspension medium containing EC9706 and Eca109 cells was loaded onto the top chamber of the transwell. Medium (500 $\mu \mathrm{l}$ ) containing 10\% FBS (used as a chemoattractant) was added to the bottom chamber. The cells were allowed to migrate for $12 \mathrm{~h}$ at $37^{\circ} \mathrm{C}$ in a humidified incubator with $5 \% \mathrm{CO}_{2}$. After $12 \mathrm{~h}$, the upper surface of the membrane was wiped with a cotton tip to mechanically remove non-invasive cells, and the invasive cells attached to the lower surface of the membrane were fixed with methanol and stained with crystal violet for $20 \mathrm{~min}$. The membranes were extracted and mounted onto coverslips with the cells on the upper surface. The number of cells invading the Matrigel were counted in three randomly selected visual fields from the central and peripheral portions of the filter with an inverted microscope at magnification, $\mathrm{x} 100$. Each assessment was performed in triplicate.

Cell migration was determined by performing woundhealing assays. EC9706 and Eca109 cells $\left(1 \times 10^{5}\right)$ were seeded into 24-well plates with wound healing inserts (Cell Biolabs, Inc., San Diego, CA, USA). Once cells had reached 90\% confluence, the inserts were removed with sterile forceps to create a wound field of $\sim 500 \mu \mathrm{m}$. Following removal of the cellular debris with PBS, the cells were exposed to various concentrations of $\alpha$-solanine $(0,20,40$ or $60 \mu \mathrm{g} / \mathrm{ml})$ for $24 \mathrm{~h}$. Cell migration was viewed using an inverted microscope. The wound area was scaled using Image Pro Plus 6.0 software (National Institutes of Health, Bethesda, MD, USA). The wound closure percentage was calculated using the equation: Wound closure $\%=[1-$ (wound area after $24 \mathrm{~h} /$ wound area after $0 \mathrm{~h}$ ) x 100\%.

Cell apoptosis assay. Staining with annexin V-fluorescein isothiocyanate (FITC) and propidium iodide (PI) was performed using an Annexin V-FITC/PI Apoptosis Detection kit (Vazyme Biotech Co., Ltd, Nanjing, China) to detect and quantify the number of apoptotic cells. EC9706 cells in the logarithmic phase of growth were seeded into 6-well plates with $2 \times 10^{5}$ cells in each well. The cells that were exposed to different concentrations of $\alpha$-solanine were collected and counted $48 \mathrm{~h}$ after incubation at room temperature for $10 \mathrm{~min}$ in the dark. The cell pellets were resuspended in $195 \mu \mathrm{l}$ of binding buffer and stained with $5 \mu \mathrm{l}$ each of annexin V-FITC and PI staining solution for $10 \mathrm{~min}$ at room temperature in the dark. Flow cytometry (BD FACSCanto II; BD Biosciences, Franklin Lakes, NJ, USA) was performed with the FACScan system using CellQuest software, version 7.5. The cell apoptotic rate was calculated as: (Number of apoptotic cells in each group / total number of cells in each group) $\mathrm{x} 100 \%$.

Western blot analysis. The method of cell harvesting was described earlier in the cell apoptosis assay section. Total protein was extracted from each group of cells using radioimmunoprecipitation assay buffer containing phenylmethylsulfonyl fluoride. A Bicinchoninic Acid Protein Assay kit (Beyotime Institute of Biotechnology, Haimen, China) was used to determine the total protein concentration. Protein samples $(30 \mu \mathrm{g})$ were resolved on 10\% SDS-PAGE gels and transferred onto polyvinylidene difluoride membranes. After blocking the membranes with $3 \%$ bovine serum albumin (Beyotime Institute of Biotechnology) for $1 \mathrm{~h}$, the membranes were incubated overnight at $4^{\circ} \mathrm{C}$ with mouse anti-matrix metalloproteinase (MMP)-2 (cat. no. sc-13594), MMP-9 (cat. no. sc-21733), E-cadherin (cat. no. sc-8426), B-cell lymphoma (Bcl)-2 (cat. no. sc-509), Bax (cat. no. sc-23959) and GAPDH (cat. no. sc-365062) monoclonal antibodies (1:1,000; Santa Cruz Biotechnology Inc., Dallas, TX, USA). Subsequently, the membranes were incubated with horseradish peroxidase-conjugated goat anti-mouse secondary antibody (1:1,000; cat. no. sc-2969; Santa Cruz Biotechnology). The western blots were scanned and the protein intensities were analyzed using the Typhoon ${ }^{\text {TM }}$ FLA 7000 laser scanner with Typhoon $^{\mathrm{TM}}$ FLA 7000 Control Software (GE Healthcare Life Sciences, Chalfont, UK). Experiments were performed in triplicate. 
A
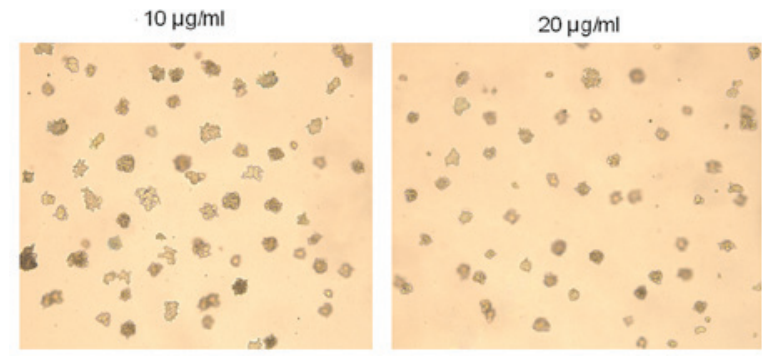

B

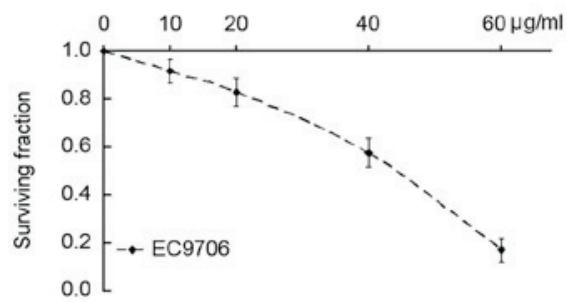

D

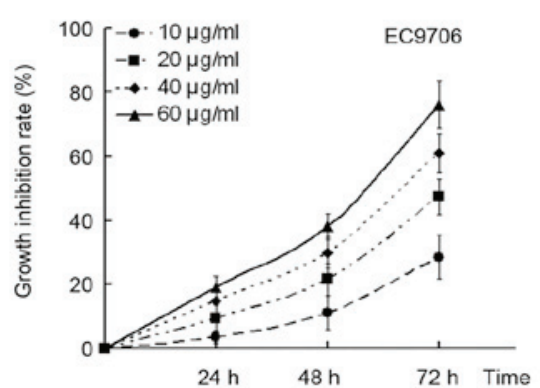

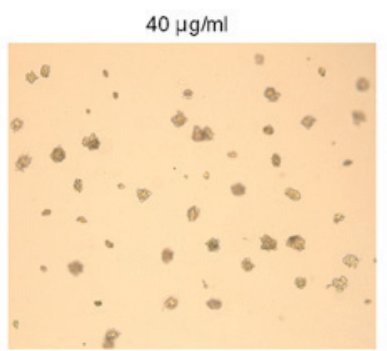

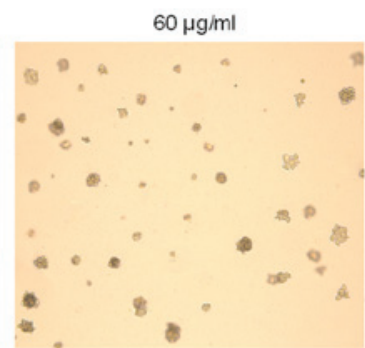

C

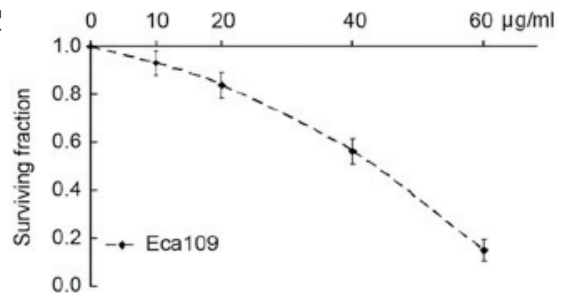

E

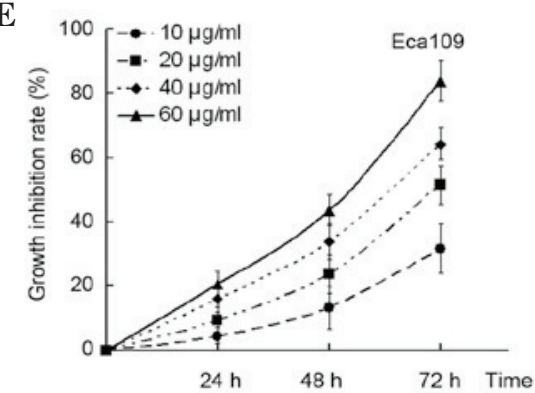

Figure 1. Effect of $\alpha$-solanine on cell viability and the potential to inhibit colony formation in EC9706 and Eca109 cells. (A) Colony formation by EC9706 cells treated with various doses of $\alpha$-solanine or dimethyl sulfoxide (control). Indication of the surviving fraction in (B) EC9706 and (C) Eca109 cells. The cells were treated with various doses of $\alpha$-solanine and colony formation assays were conducted. Compared with the control $(0 \mu \mathrm{g} / \mathrm{ml} \alpha$-solanine), the clonogenic survival of EC9706 and Eca109 cells treated with different doses of $\alpha$-solanine were significantly decreased, and the clonogenic survival effect of $\alpha$-solanine was dose-dependent. The growth inhibition rate in (D) EC9706 and (E) Eca109 cells. $\alpha$-solanine inhibited the proliferation of esophageal carcinoma cells. EC9706 and Eca109 cells were treated with various concentrations of $\alpha$-solanine or dimethyl sulfoxide (control), and cell proliferation was assessed using the Cell Counting kit- 8 assay. The growth inhibitory effect of $\alpha$-solanine was time- and dose-dependent, with the maximum inhibition detected $72 \mathrm{~h}$ after treatment. Data are presented as the mean \pm standard deviation $(n=3)$.

Caspase-3/7 activity assay. Cells from each $\alpha$-solanine-treated group were collected as described in the cell apoptosis assay section earlier. Caspase 3/7 activity was measured using a Caspase-Glo 3/7 assay (Promega Corporation, Madison, WI, USA). The plates were incubated at room temperature for $1 \mathrm{~h}$, and $100 \mu \mathrm{l}$ Caspase-Glo 3/7 reagent was added after the incubation period. Luminescence intensity was then detected using a microplate reader (Infinite 200 PRO; Tecan Trading AG, Männedorf, Switzerland).

Statistical analysis. SPSS statistical software (version 16.0; SPSS, Inc., Chicago, IL, USA was used for statistical analysis. One-way analysis of variance (ANOVA) was used to analyze the significance between groups. Multiple comparisons were made using Fisher's Least Significant Difference test when the probability indicated by ANOVA was statistically significant. Data are presented as the mean \pm standard deviation. $\mathrm{P}<0.05$ was considered to indicate a statistically significant difference.

\section{Results}

$\alpha$-solanine affects cell viability and inhibits colony formation. To determine the effects of $\alpha$-solanine on tumor cells, a clonogenic survival analysis was performed. It was observed that the treatment of EC9706 and Eca109 EC cells with various concentrations of $\alpha$-solanine $(10,20,40$ and $60 \mu \mathrm{g} / \mathrm{ml})$ exerted an inhibitory effect on clonogenic survival. Furthermore, the inhibitory effect was more pronounced when the concentration of $\alpha$-solanine was increased (Fig. 1A-C).

A CCK-8 assay was performed to measure the effect of $\alpha$-solanine on the growth and viability of EC9706 and Eca109 cells in vitro. Compared with the control, (without $\alpha$-solanine), cell proliferation was markedly inhibited at different concentrations in the $\alpha$-solanine group in a dose- and time-dependent manner (Fig. 1D and E). These results suggested that $\alpha$-solanine may function as a tumor suppressor in EC cells in vitro.

$\alpha$-solanine decreases the invasion and migration ability of EC9706 and Eca109 cells. A transwell assay was conducted in addition to a wound-healing assay to evaluate the effect of $\alpha$-solanine on the invasion and migratory activity of EC9706 and Eca109 cells. The cells were treated with 0, 20,40 and $60 \mu \mathrm{g} / \mathrm{ml} \alpha$-solanine, and then placed in the transwell chambers. Fig. 2A and B shows the average number of migrating cells penetrating the transwell membrane following treatment with different concentrations of $\alpha$-solanine. The results indicated that the average number of migrating cells 
A

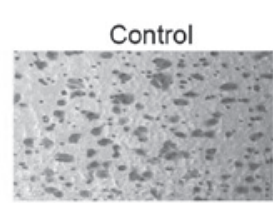

$40 \mu \mathrm{g} / \mathrm{ml}$

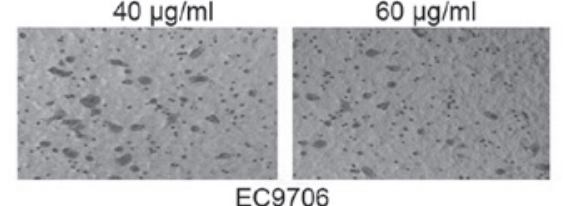

EC9706

C

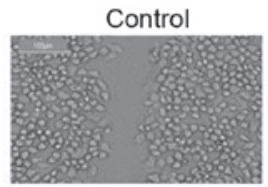

$40 \mu \mathrm{g} / \mathrm{ml}$

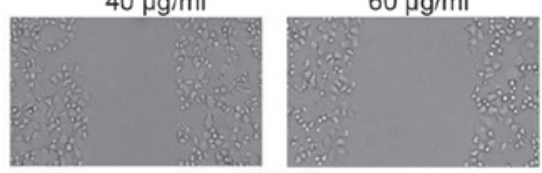

B

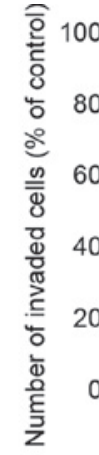

D

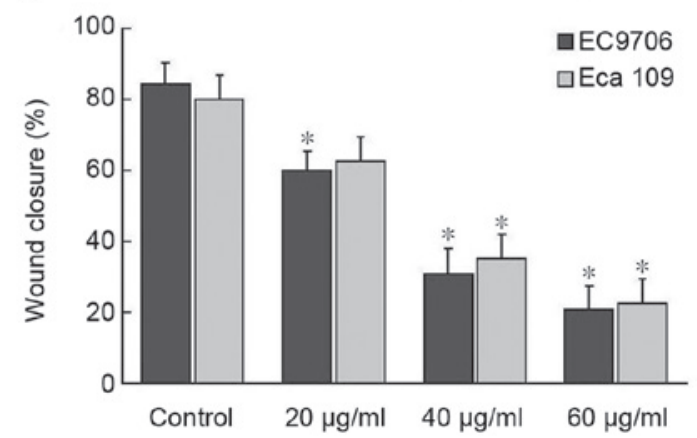

Figure 2. Cell migration and invasion assays. The cells were treated with various concentrations of $\alpha$-solanine for 24 h. (A) The invaded EC9706 cells were photographed (magnification, x100). (B) The invaded cells were quantified by counting stained cells in each concentration $\alpha$-solanine groups. (C) The wound area of EC9706 cells was photographed. (D) The wound area was quantified in each group. Data were calculated from three independent experiments and presented as the mean of triplicate experiments. The averages of triplicate samples are shown. Error bars indicate the standard deviation. ${ }^{*} \mathrm{P}<0.05$ vs. control group.

penetrating the transwell membrane was significantly lower for each concentration of $\alpha$-solanine, compared with the control group $(\mathrm{P}<0.05)$. The effect of $\alpha$-solanine on the migration of cells indicated dose-dependency.

Fig. 2C and D reveal the migratory ability in the treatment group. The control group had reached a higher cell density at $24 \mathrm{~h}$ post-wounding compared with each of the $\alpha$-solanine-treated groups in the two cell lines. These data indicate that $\alpha$-solanine suppressed the migration and invasion of EC cells in a dose-dependent manner.

$\alpha$-solanine induces apoptosis in EC9706 cells. To investigate the ability of $\alpha$-solanine to induce cell apoptosis, we used flow cytometry to measure the effect of different concentrations of $\alpha$-solanine on apoptosis in EC9706 cells. The cells found to be annexin $\mathrm{V}$-positive or annexin $\mathrm{V}$ - and PI-positive were defined as apoptotic cells (Fig. 3A). Compared to the control, the apoptotic rate of EC9706 cells was increased following treatment with each concentration of $\alpha$-solanine compared with the control group $(\mathrm{P}<0.05)$. Furthermore, the apoptotic rate was significantly enhanced with increasing concentrations of $\alpha$-solanine $(\mathrm{P}<0.05$; Fig. $3 \mathrm{~B})$.

To further assess the effect of $\alpha$-solanine on tumor cell apoptosis, a caspase-3/7 activity assay was performed. As shown in Fig. 3C, the caspase-3/7 activity was higher in the $\alpha$-solanine group compared with the control group $(\mathrm{P}<0.05)$. These results demonstrate that $\alpha$-solanine is able to induce the apoptosis of EC cells.

a-solanine suppresses the expression of metastasis-associated molecules in EC9706 cells. Subsequent to establishing that $\alpha$-solanine was able to decrease the invasion and migration ability of EC cells, the underlying molecular mechanism was investigated. To determine whether $\alpha$-solanine exerted its inhibitory function on tumor cells by regulating the protein expression levels of matrix MMP-2, MMP-9 and E-cadherin, a western blot analysis was performed to determine the expression levels in $\alpha$-solanine-treated EC9706 cells. The MMPs are crucial molecules for extracellular matrix (ECM) degradation, which induces cell invasion. The results indicated that $\alpha$-solanine suppressed the expression of MMP-2 and MMP-9 in a dose-dependent manner (Fig. 4). Furthermore, E-cadherin expression levels were significantly higher in each of the $\alpha$-solanine-treated groups compared with those in the control group (Fig. 4). Thus, $\alpha$-solanine is able to upregulate the expression levels of E-cadherin, which may increase cell adhesion, thereby indicating that $\alpha$-solanine may be able to inhibit metastasis by affecting the proteolytic activation and adhesive capacity of cells.

$\alpha$-solanine influences the protein expression levels of apoptosis-associated genes. The protein expression levels of Bcl-2 and Bax, which are associated with cell apoptosis, were determined by western blot analysis. Compared with the control group, the expression levels of Bcl-2 were decreased in the $\alpha$-solanine-treated groups, while the expression levels of Bax were increased significantly $(\mathrm{P}<0.05$; Fig. 4). Furthermore, the protein expression levels of Bcl-2 and Bax were observed to alter in a dose-dependant manner.

\section{Discussion}

Glycoalkaloids are produced in the sprouts, roots and tubers of the potato plant, and are involved in the resistance of the 

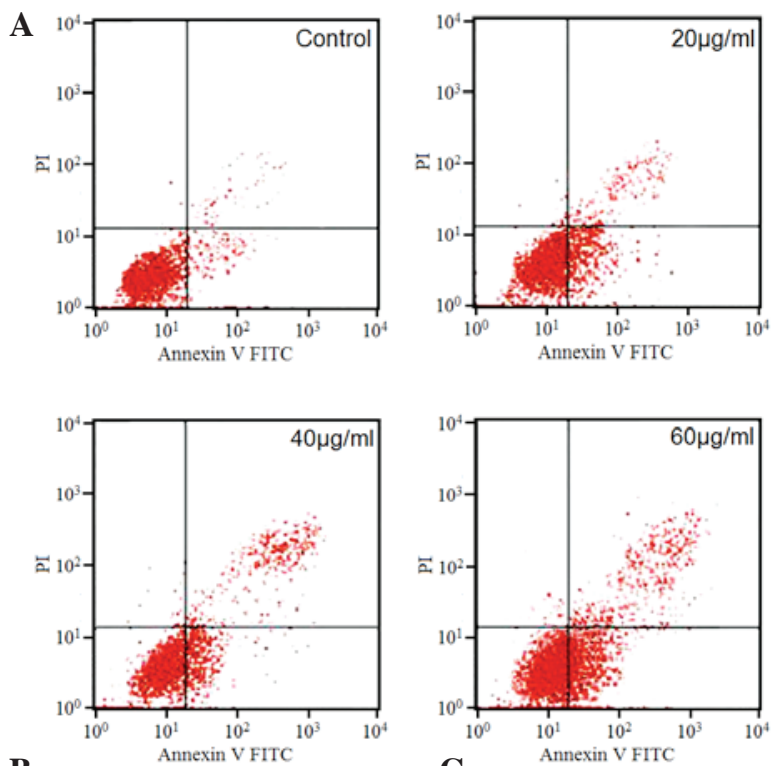

C
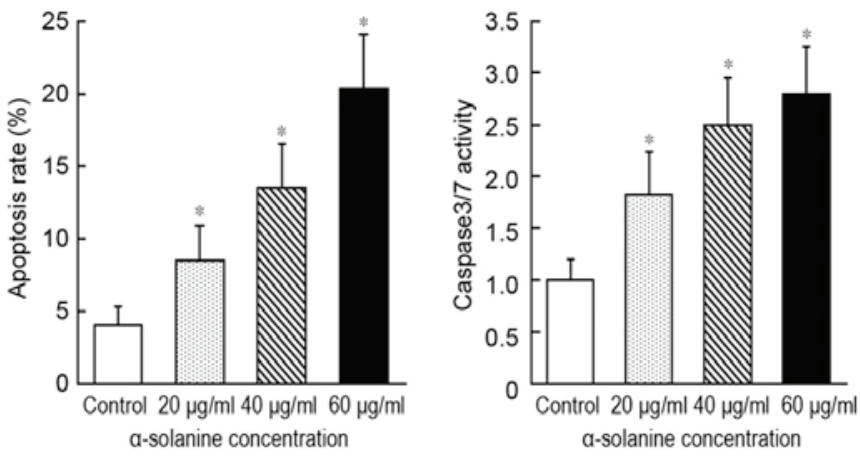

Figure 3. $\alpha$-solanine induces apoptosis in EC9706 cells. (A) Cell apoptosis was analyzed by flow cytometry. (B) Quantified results of flow cytometry analysis. The number of apoptotic cells was increased significantly in EC9706 cells treated with various concentrations of $\alpha$-solanine compared with the control group $(\mathrm{P}<0.05)$. (C) The results of the caspase-3/7 activity assay. The caspase-3/7 activity was higher in the $\alpha$-solanine-treated groups compared with the control group $(\mathrm{P}<0.05)$. Data are presented as the mean \pm standard deviation of triplicate experiments. " $\mathrm{P}<0.05$ vs. control group.

host-plant to bacteria, fungi, viruses and insects (6). Previous studies have reported that glycoalkaloids are able to suppress the cell growth of human cervical, liver, stomach, colon and skin cancers $(8,10,18)$. $\alpha$-solanine is a major glycoalkaloids. High concentrations of $\alpha$-solanine can cause cytotoxic effects that induce rapid damage to the plasma membrane, leading to lethal metabolic disorders $(10,19,20)$. In addition to the toxic effects of $\alpha$-solanine in normal physiological functions, the compound has the potential to be cytotoxic against cancer cells. Previous studies have demonstrated that $\alpha$-solanine exhibits anticarcinogenic potential, such as through inhibiting the growth of various cancer cells and inducing apoptosis in human colon cancer cells $(8,9,11-14)$. Therefore, it is reasonable to hypothesize that $\alpha$-solanine is a potentially effective therapy against human EC cells tumor cells.

To assess this hypothesis, initial colony formation and proliferation assays were conducted in the EC9706 and Eca109 EC cell lines. It was observed that the cancer cells treated with different concentrations of $\alpha$-solanine showed significantly decreased proliferation and surviving fraction of

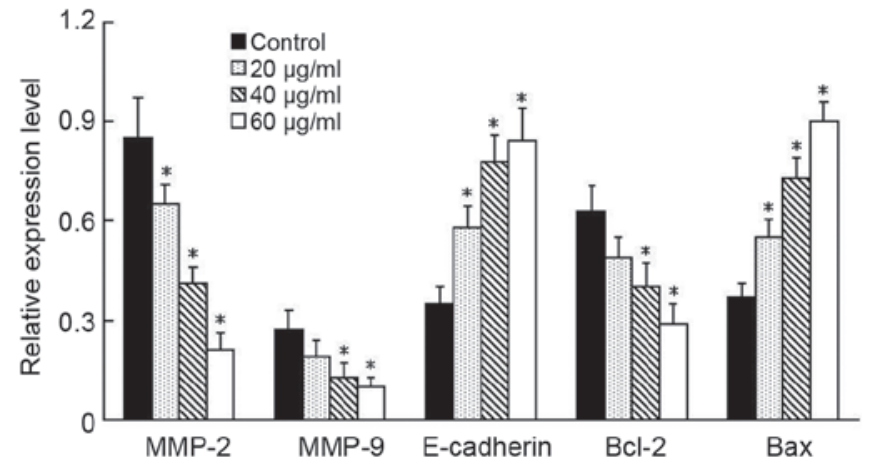

Figure 4. $\alpha$-solanine induces apoptosis and decreases cancer cell invasion and migratory ability on the alteration of the gene expression, as determined by western blot analysis. EC9706 cells were seeded into 6-well plates and treated with the indicated concentration $\alpha$-solanine. After $48 \mathrm{~h}$, total protein was extracted for western blot analysis. The relative expression levels of MMP-2, MMP-9, E-cadherin, Bcl-2 and Bax from each independent experiment are shown. Greater alterations in the protein expression levels were observed as the concentration of $\alpha$-solanine increased, indicating that $\alpha$-solanine could promote apoptosis and decrease the invasion and migration ability of EC9706 cells by regulating the expression levels of MMP-2, MMP-9, E-cadherin, Bcl-2 and Bax. Data are presented as the mean \pm standard deviation of triplicate experiments. ${ }^{*} \mathrm{P}<0.05$ vs. control. MMP, matrix metalloproteinase; Bcl-2, B-cell lymphoma.

cells. In addition, the inhibitory effect of $\alpha$-solanine was timeand dose-dependent, with the maximum inhibition detected at $72 \mathrm{~h}$ after treatment. These data demonstrated that $\alpha$-solanine has potential as a therapy to treat EC cells in vitro.

Apoptosis has previously been demonstrated to be the major cause of cell death. It is now widely recognized that drug-induced apoptosis may be used to measure the sensitivity of cells to therapies, with an increased rate of apoptosis indicating that the cells have a higher sensitivity to chemotherapy $(21,22)$. The current study examined the apoptotic effect induced by $\alpha$-solanine at different concentrations. The results indicated that $\alpha$-solanine significantly induced apoptosis in EC cells compared with the control, and the effects of treatment with higher concentrations of $\alpha$-solanine were greatest. To further investigate the mechanism underlying the action of $\alpha$-solanine on tumor cells apoptosis, the expression levels of Bcl-2, and Bax were determined, in addition to the caspase activity (caspase-3/7), which serves an important role during cell apoptosis (23-25). The data revealed that $\alpha$-solanine was able to efficiently decrease Bcl-2 and increase Bax expression levels, in addition to increasing caspase-3/7 activity, indicating that $\alpha$-solanine induced the apoptosis of cancer cells.

Furthermore, to evaluate the effect of $\alpha$-solanine on the invasion and migratory activity of EC9706 and Eca109 cells, transwell and wound-healing assays were performed. The results revealed that $\alpha$-solanine was able to prevent the penetration of cancer cells through the transwell membrane, and inhibited the migratory ability of EC9706 and Eca109 cells in a dose-dependent manner. Tumor metastasis is a complex multistep process, in which cancer cells invade the basement membrane and ECM, and this process is promoted by various proteolytic enzymes. The MMPs are a family of zinc-containing endopeptidases with an important role in tumor cell migration, tissue invasion and metastasis $(26,27)$. 
MMP-2 and MMP-9 serve particularly important roles in the process of metastasis among the MMPs $(28,29)$. Therefore, the effects of $\alpha$-solanine on MMP-2 and MMP-9 expression levels were investigated in the present study. The results indicated that expression levels of MMP-2 and MMP-9 were significantly downregulated in the $\alpha$-solanine-treated groups . In addition, cell adhesion molecules serve to regulate cell polarity, differentiation, proliferation and migration through an association with the actin cytoskeletal network (30). In the present study, it was ascertained that the expression of E-cadherin was significantly increased in EC cells treated with $\alpha$-solanine. These results suggest that the effect of $\alpha$-solanine on MMP-2/9 and E-cadherin may be, at least in part, responsible for its anti-metastatic potential.

In conclusion, the inhibition of cancer cell proliferation and metastasis is an important aspect in cancer prevention and treatment. The results of the current study demonstrate that $\alpha$-solanine was able to inhibit the proliferation and invasion of EC9706 and Eca109 cells in vitro, and induced apoptosis in these cells. Thus, as it has been indicated that $\alpha$-solanine possesses antitumor properties, its use in the development of chemopreventive and/or chemotherapeutic agents for the treatment of EC is important. The current results constitute a novel insight into the anti-tumor mechanism of $\alpha$-solanine, and suggest that $\alpha$-solanine is a potential agent for the prevention and treatment of EC. Further studies should investigate the effect of $\alpha$-solanine on EC cells in vivo.

\section{Acknowledgements}

The present study was supported by the Education Department of Henan Province Science and Technology Research Projects (grant nos. 12A310015 and 13A310671).

\section{References}

1. Jemal A, Bray F, Center MM, Ferlay J, Ward E and Forman D: Global cancer statistics. CA Cancer J Clin 61: 69-90, 2011.

2. Szumiło J: Epidemiology and risk factors of the esophageal squamous cell carcinoma. Pol Merkur Lekarski 26: 82-85, 2009 (In Polish).

3. Yamashina T, Ishihara R, Nagai K, Matsuura N, Matsui F, Ito T, Fujii M, Yamamoto S, Hanaoka N, Takeuchi Y, et al: Long-term outcome and metastatic risk after endoscopic resection of superficial esophageal squamous cell carcinoma. Am J Gastroenterol 108: 544-551, 2013.

4. Park B, Jun JH, Jung J, You S and Lee MS: Herbal medicines for cancer cachexia: Protocol for a systematic review. BMJ Open 4: e005016, 2014

5. Leng JC and Gany F: Traditional Chinese medicine use among Chinese immigrant cancer patients. J Cancer Educ 29: 56-61, 2014.

6. Friedman M: Potato glycoalkaloids and metabolites: Roles in the plant and in the diet. J Agric Food Chem 54: 8655-8681, 2006.

7. Kuo CI, Chao $\mathrm{CH}$ and Lu MK: Effects of auxins on the production of steroidal alkaloids in rapidly proliferating tissue and cell cultures of Solanum lyratum. Phytochem Anal 23: 400-404, 2012.

8. Friedman M, Lee KR, Kim HJ, Lee IS and Kozukue N: Anticarcinogenic effects of glycoalkaloids from potatoes against human cervical, liver, lymphoma and stomach cancer cells. J Agric Food Chem 53: 6162-6169, 2005.
9. Yang SA, Paek SH, Kozukue N, Lee KR and Kim JA: Alpha-chaconine, a potato glycoalkaloid, induces apoptosis of HT-29 human colon cancer cells through caspase-3 activation and inhibition of ERK 1/2 phosphorylation. Food Chem Toxicol 44: 839-846, 2006

10. Lee KR, Kozukue N, Han JS, Park JH, Chang EY, Baek EJ, Chang JS and Friedman M: Glycoalkaloids and metabolites inhibit the growth of human colon (HT29) and liver (HepG2) cancer cells. J Agric Food Chem 52: 2832-2839, 2004.

11. Lu MK, Shih YW, Chang Chien TT, Fang LH, Huang HC and Chen PS: $\alpha$-Solanine inhibits human melanoma cell migration and invasion by reducing matrix metalloproteinase-2/9 activities. Biol Pharm Bull 33: 1685-1691, 2010.

12. Lv C, Kong H, Dong G, Liu L, Tong K, Sun H, Chen B, Zhang C and Zhou M: Antitumor efficacy of $\alpha$-solanine against pancreatic cancer in vitro and in vivo. PLoS One 9: e87868, 2014.

13. Sun H, Lv C, Yang L, Wang Y, Zhang Q, Yu S, Kong H, Wang M, Xie J, Zhang C and Zhou M: Solanine induces mitochondria-mediated apoptosis in human pancreatic cancer cells. Biomed Res Int 2014: 805926, 2014.

14. Ji YB, Gao SY, Ji CF and Zou X: Induction of apoptosis in HepG2 cells by solanine and $\mathrm{Bcl}-2$ protein. $\mathrm{J}$ Ethnopharmacol 115 : 194-202, 2008

15. Lu MK, Chen PH, Shih YW, Chang YT, Huang ET, Liu CR and Chen PS: Alpha-Chaconine inhibits angiogenesis in vitro by reducing matrix metalloproteinase-2. Biol Pharm Bull 33: 622-630, 2010.

16. Gao SY, Wang QJ and Ji YB: Effect of solanine on the membrane potential of mitochondria in HepG2 cells and [Ca2+]i in the cells. World J Gastroenterol 12: 3359-3367, 2006.

17. Rosenkranz V and Wink M: Induction of apoptosis by alkaloids. non-protein amino acids and cardiac glycosides in human promyelotic HL-60 cells. Z Naturforsch C 62: 458-466, 2007.

18. Cham BE and Meares HM: Glycoalkaloids from Solanum sodomaeum are effective in the treatment of skin cancers in man. Cancer Lett 36: 111-118, 1987.

19. Yamashoji S and Matsuda T: Synergistic cytotoxicity induced by $\alpha$-solanine and $\alpha$-chaconine. Food Chem 141: 669-674, 2013.

20. Friedman M, Henika PR and Mackey BE: Effect of feeding solanidine, solasodine and tomatidine to non-pregnant and pregnant mice. Food Chem Toxicol 41: 61-71, 2003.

21. Konstantinidou AE, Korkolopoulou P and Patsouris E: Apoptotic markers for tumor recurrence: A minireview. Apoptosis 7: 461-470, 2002.

22. Yano M, Inoue M and Shiozaki H: Preoperative concurrent chemotherapy and radiation therapy followed by surgery for esophageal cancer. Ann Thorac Cardiovasc Surg 8: 123-130, 2002.

23. Hsia JY, Chen CY, Hsu CP, Shai SE, Yang SS, Chuang CY, Wang PY and Chen JT: Expression of apoptosis-regulating proteins $\mathrm{p} 53, \mathrm{Bcl}-2$ and Bax in primary resected esophageal squamous cell carcinoma. Neoplasma 48: 483-488, 2001.

24. Hunter AM, LaCasse EC and Korneluk RG: The inhibitors of apoptosis (IAPs) as cancer targets. Apoptosis 12: 1543-1568, 2007.

25. Kuribayashi K, Mayes PA and El-Deiry WS: What are caspases 3 and 7 doing upstream of the mitochondria? Cancer Biol Ther 5: 763-765, 2006.

26. Vargová V, Pytliak M and Mechírová V: Matrix metalloproteinases. EXS 103: 1-33, 2012.

27. Pytliak M, Vargová V and Mechírová V: Matrix metalloproteinases and their role in oncogenesis: A review. Onkologie 35: 49-53, 2012.

28. Hofmann UB, Westphal JR, Van Muijen GN and Ruiter DJ: Matrix metalloproteinases in human melanoma. J Invest Dermatol 115: 337-344, 2000.

29. Bauvois B: New facets of matrix metalloproteinases MMP-2 and MMP-9 as cell surface transducers: Outside-in signaling and relationship to tumor progression. Biochim Biophys Acta 1825: 29-36, 2012.

30. Buda A and Pignatelli M: E-cadherin and the cytoskeletal network in colorectal cancer development and metastasis. Cell Commun Adhes 18: 133-143, 2011. 